\title{
PEUGEOT CELEBRATES ITS 200 YEARS OF LIFE. HISTORY, STRATEGIES, ORGANIZATION AND FUTURE PROSPECTS OF THE FRENCH CAR COMPANY. A COMPARISON WITH FIAT AUTO.
}

\author{
Francesco SCALERA \\ University of Bari “Aldo Moro", Italy
}

\begin{abstract}
The motor industry is suffering more than other sectors from the effects of the current international crisis with a widespread drop in sales affecting almost all the main world producers, due to two factors that can be described as follows. On one side, the shrinkage in family per capita income inducing the consumer to spend less on luxury goods (like cars); on the other one, the high upkeep of cars because of a sharp increase in the cost of fuel, of insurance as well as of road tax, particularly in some European countries (like Italy).

In addition to this ruinous economic situation reducing the car producing companies' receipts, the high costs to be born to renew the industrial plants in compliance with the environmental regulations as well as to design products that are able to meet the consumer's changing needs led motor companies to reorganize their competitive strategies with growing attention, as compared to the past, to a kind of strategy oriented to "innovation and flexibility", allowing the design of new high technology products that are environment-friendly and energy saving with low selling prices compared to the quality offered.
\end{abstract}

In particular, these goals can be achieved by implementing such strategies as those pursued by some producers in recent years: significant mergers with other car companies aimed at combining their individual peculiarities in order to properly widen the range of products offered; production relocation to emerging countries in order to profit from low costs of row materials and labour to minimize production costs; boosting research and development to design cars that are able to run with alternative energy sources; re-launching neglected brands through creative promotional campaigns that are likely to stir up new emotions in the consumer.

As a result, the present work is mainly intended to analyse the strategic evolution of one of the most ancient motor companies on the international scene, namely Peugeot, to weigh up the situation, on the occasion of its bicentenary, about the innovative ideas brought into the market, the kind of organizational structure adopted within the company itself, as well as the future prospects of the transalpine firm.

In particular, after a rapid historical survey of the firm, the paper is going to assess whether the strategic choices made are able to meet the above-mentioned successful factors, in order to assume the possible result that the new models suggested are likely to achieve on the consumer's market.

Afterwards, the most suitable organizational structure to be adopted to support the strategic choices made in the present market conditions will be examined; finally, the dissertation will end by comparing such internationalization strategies with those implemented by the transalpine competitor, namely Fiat, in order to assume which of the two strategic choices could turn out to be the most performing one in the future.

Keywords: Peugeot, Strategies, Internationalization, Production, Fiat 


\section{INTRODUCTION}

Before entering the strategic analysis of PSA Peugeot Citroen it is perhaps useful to analyze the competitive scene of the automotive market, in order to understand its own peculiarities and its evolution as well as the critical success factors to be met to ensure competitiveness, so that to assess, afterwards, whether the strategic dynamics of the Group comply with the expectations of customers that have become, at the same time, increasingly demanding.

In this regard, it is important to point out that the automotive market is among the most dynamic and complex ones, due to a number of special features characterizing it, that can be described as follows: the huge investment needed to implement innovative models, the high technological level of the product, the wide range of the goods offered, their high value, the fragmentation of suppliers involved in the production of the car and so on. Currently, the motor sector is the one that is mostly suffering from the international crisis in the last two years, although it slowly started to recover in the second half of 2010, with increased sales in the leading European producers. However, the new political instability, caused by the wars that are affecting the countries of the Middle East (Tunisia, Egypt, Libya, Syria, Yemen, Bahrain), the major oil producers, has led to soaring fuel costs, whose rise is even due to speculative manoeuvring, thus seriously endangering the motor companies' recovery.

Therefore, in the light of the recent events, among the already known critical success factors to be met, such as the product quality and innovation, minimized production costs, the organizational flexibility to comply readily with the market evolution, it seems that, as compared to the past, international manufacturers are increasingly oriented to favour technological research, aimed on the one hand, at protecting the environment through reducing $\mathrm{CO} 2$ emissions and, on the other one, at dramatically reducing fuel consumption during the current serious energy crisis.

However, the scenario that has just described, has changed not only the strategies of the leading producers, but also the demand for cars at an international level, allowing those car manufacturers that are able to penetrate promptly new market segments, to achieve significant competitive advantages.

In particular, as regards the supply of the product, the automotive market evolution trends show that the major manufacturers tend to relocate upstream activities, including the final assembly, to Eastern Europe, by exploiting the competitive advantage of the low cost labour force in those countries, while the presence in the BRIC countries (Brazil, Russia, India, China) is explained by a strong technology transfer that, by the time passing, will lead the countries benefiting from the technology to become totally autonomous.

These choices have brought about a lack of jobs in industrialized countries which, together with the end of incentives for car scrapping, has led the car company to experience a serious financial and social crisis (as shown by the events that have lately involved Fiat in Italy).

On the other side, as regards the supply, it is clear that the international economic crisis has created a divergence of trends in car registrations between the USA and the European Union, on the one hand, and such countries as China, India and Brazil on the other one. In fact, if the former have reduced registrations because of the recession, the latter experienced registration increase significantly due to a highly positive GDP (Gross Domestic Product), even in such a difficult period like the current one.

As for the new market segments, the cars equipped with gas or methane engines are increasingly making their way together with hybrid and electric cars, in particular, that represent the vehicles of the future, especially in such countries like Italy which have no oil wells and power plants.

Confirming this trend, one of the most attractive markets in the sector is definitely the Chinese one, for two reasons.

The first one is that, in 2009 , the Chinese market was characterized by a production capacity of about 17 million cars, that is expected to grow in the future, and a large concentration of producers (the first 10 covered about $87.15 \%$ of the total), which makes one understand that this market, at present, has not any problem of exceeding capacity. The second reason is that the Chinese Government has included, in its five-year plan, the so called "new energy" plan among the seven strategic emerging industries supported by tax measures such as governmental incentives as well as tax reduction or exemption; the above sector will benefit from a public investment of 1.46 billion Dollars to fund technological research and the production of special components for electric cars, and its market is expected to reach between $5 \%$ and $10 \%$ of the total sales of cars in the near future. 


\section{THE HISTORY OF PSA PEUGEOT CITROEN}

Before starting the strategic analysis of the Group, it is convenient to give a rapid historical survey, in order to understand the origins of the brand that has just celebrated 200 years of life.

Its history begins in 1810, when the Peugeot brothers turned the ancient family mill into a still foundry, launching the production of saw-blades under the name of "Peugeot Frères".

As from 1833, the production was diversified and widened to include belt saws, umbrellas, coffee grinders as well as pepper grinders.

Afterwards, in 1858, Emile Peugeot patented the famous Lion Rampant tolly distinguishing the products of the transalpine company, starting from the first velocipede produced under the Peugeot trademark, namely the "Grand Bi", dating back to 1882 .

However, the true motor company, known worldwide under the name of "Société des Automobiles Peugeot" was set up in 1886, though it was not until 1929 that the first car was marketed, namely the 201, equipped with independent front wheels.

After the collaboration started in 1955 with the Italian designer Pininfarina, resulting in the production of the 403 model, another important stage for the development of the transalpine company was reached in 1965, when it took the judicial status of SA Peugeot converted in 1976 following the merger with another popular French car brand, namely Citroen (Tanca 2010).

The 80s and 90s saw the presidency of J. Calvet that, in 1992, decided to transform the company into the PSA Peugeot Citroen Group, which is, today, the second European motor manufacturer and whose president has been Mr. Philippe Varin. since 2009 (Giorgi 2009).

\section{PSA PEUGEOT CITROEN GROUP'S DEVELOPMENT STRATEGIES}

After the brief historical overview on the transalpine Group, the present research is now going to focus on its development strategies, to assess whether or not they are in line with the consumer's expectations, as well as whether they fulfill the critical success factors suggested by the market.

In this regard, in 2007, PSA Peugeot Citroen Group decided to pursue, among its strategies of action, the goal of sustainable development, implementing a plan called " 10 sustainable development objectives for 2010-2011" in four areas, namely environment, social responsibility, governance and society; following the expectations of the Group, these aims should allow the company to pursue the ambitious goal of rising from tenth, at present, to seventh in the world producers rankings by 2015 (Bourassi 2010).

As regards the first issue, they focused on the following: the drastic cut in carbon dioxide emissions below the threshold of 120 grams of $\mathrm{CO} 2$ per km., which allowed a sale of about two million vehicles in the period 2007-2010; the development of eco-design aiming at using the massive percentage of green materials (i.e. recycled organic materials, natural materials, polymers that do not come from the petrochemical industry); the construction, in 2011, of vehicles having a polymer content of $20 \%$ and, finally, the environmental management aiming at reducing the energy consumed for each car to be produced.

The goal of social responsibility has already been pursued for several years and the Transalpine Group is in the lead compared to other manufacturers because, since 2003, the Group has been part in the agreement called Global Compact, providing for the Universal Declaration of Human Rights, the Declaration on Fundamental Principles and Rights at Work, the Rio Declaration on Environment, the United Nations Convention against Corruption and, since 2009, the United Nations initiative called "Caring for Climate".

For these agreements, the Group intends to involve trade unions and engineering industries and is committed to foster the staff's growth, the workers' safety and welfare, social cohesion, the respect and promotion of the employees' rights.

With regard to corporate governance, it will focus mainly on a better dialogue with shareholders on the implementation of socially responsible investment, as well as on greater awareness of their responsibility for suppliers that must be all certified according to ISO (International Standards Organization) regulations providing for the satisfaction of such standards as price, quality, service and time to market. 
Finally, concerning the social commitment, the Group has focused its attention on the safety of passengers, on the spreading of communication services such as, for example, emergency call systems, with which 1 million vehicles are going to be equipped in 10 European countries by 2011 . Besides, a charter for responsible communication has been worked out, whose main task is to define the standards of social responsibility for all the advertisements made by the Group and by the Group-related brands.

As for the strategic choices made for re-launching the Group, they were centred on a restyling of their image, focusing on a redesign of the mark, new innovative advertising campaigns, on a renovation of the product range, on the development of environmentally friendly products, on an efficient after-sales service and on strategic and operational alliances enhancing also the international image of the Group, in order to facilitate the entry into these emerging markets, where the automotive industry shows a clear growth trend.

In particular, considering the strategic dynamics of the Group, it can be noted that the historic Lion Rampant logo has become more aggressive, dynamic and modern, because of its three-dimensional drawing made on a background coloured with a stronger shade of blue than in the past.

As for the new advertising campaign, it is based on a spot that, by the "Motion \& Emotion" message aims at proving how the transalpine company intends to focus on the emotional side of the cars produced, on respecting the environment, that has increasingly become a critical success factor to be met to ensure competitiveness as well as on the search for solutions to achieve a complete urban mobility, through the production of cars as well as of commercial vehicles, scooters and bicycles.

Thus, in order to promote the new brand identity internationally, the renovating program includes the new stylistic manifesto which aims at innovating some models of the cars, to make them more appealing to consumers.

Another point on which the Group's strategy has focused is the variety of the range, with the production of 14 new environmentally friendly models by 2012, to meet the demands of both Western consumers and emerging countries that have become increasingly demanding (Gemelli 2010).

In detail, a line of "custom-built" cars started by RCZ is expected to be introduced on the market, together with low environmental impact motor vehicles such as the 3008 HYbrid4 (a $200 \mathrm{HP}$ four-wheel drive hybrid diesel reducing fuel consumption by as much as $35 \%$ ) as well as the creation of a new family of 3-cylinder gasoline engines.

In addition, the BB1 production represents the join between cars and scooters; it is a small city electric car, $100 \%$ emission-free, about two metres and a half long and with a very special look, as it seems made up of two side by side scooters, which are incorporated in a single compartment with a handlebar instead of the steering wheel and with two long motor-bike saddles to place the four passengers expected (Tanca 2010).

As regards standard-luxury segments, Peugeot is launching the 508 model that would replace the 407; the new model shows an innovative body style, better use of the driver and passenger internal compartment and very low $\mathrm{CO} 2$ consumption and emissions.

As for the future, based on $50 \%$ funding, amounting to 200 million Euros granted by the European Investment Bank (EIB) to Peugeot, as part of the ECTF (European Clean Transport Facility) funding program, in order to reduce drastically $\mathrm{CO} 2$ emission, the latter will introduce plug-in hybrid technology to be used from diesel-hybrid HYbrid4 rechargeable engine, which is going to represent a real breakthrough in terms of emissions with the ambitious goal of achieving less than 50 grams of $\mathrm{CO} 2 /$ $\mathrm{km}$. with $2.0 \mathrm{l} / \mathrm{km}$. consumption (Sciarra $2010 \mathrm{a}$ ).

Another distinguishing feature is the expansion of after-sales services with the introduction of the innovative "Mu by Peugeot", an initiative that allows you to rent any car of the transalpine company at any official Peugeot dealer, through a system of progressive Credit cards based on "units of mobility". In detail, the card, that is rechargeable via the Internet, not only allows you to rent cars, but also accessories (such as GPS or roof bars) as well as to buy the services provided by some partners (travels, airplane or train tickets, hotel rooms, etc.) (Tanca 2010).

From the point of view of international alliances, the transalpine Group and the Fiat Group are likely to join for the production of cars, a solution that would supplement the collaboration already started since 1978 between the two producers with regard to commercial vehicles. 
In fact, the cooperation in this segment, which started with the creation of a platform for industrial commercial light vehicles developed under the direction of Fiat, has continued over the time with the creation of a second platform, this time under the direction of PSA Peugeot Citroen Group, for the production of middle-sized space-wagons and commercial vehicles produced in the factory of Sevelnord in Valenciennes, then ending with the final agreement reached in 2008 with Tofas, to build small-sized commercial vehicles.

This cooperation made it possible to renew more promptly the range, to keep pace with the present times, to fully satisfy the expectations of professionals and companies and to share costs and resources between the two producers.

Thus, the increased load capacity of trucks, a more appealing style of design, the best performance on the road and more suitable equipment in terms of comfort and safety allowed successful results to be achieved, considering that the two brands rank $1^{\text {st }}$ in Europe for large vans and $3^{\text {rd }}$ for the compact ones.

The alliance recently signed between Renault and Mercedes is likely to lead to an acceleration of the Agreement between PSA Peugeot Citroen and Fiat with the birth of a mega group that can produce nearly 6 million vehicles per year (represented by the sales of 2 million vehicles by Fiat in 2009, 1.3 million by Chrysler and 3.2 million by PSA Peugeot Citroen) (Montrone 2010).

However, the above merger could be hindered by the joint venture just made, on an equal basis, between Peugeot Citroen and the German company BMW to develop new technologies for hybrid engines. This joint venture, called "BMW Peugeot Citroen Electrification", that is going to be operational by the second quarter of 2011, should focus on the study and production of components, batteries and retrieval systems and management software, aimed at increased penetration of the hybrid market and at the extension of the current agreement providing only the joint development of the new Euro 6 four-cylinder gasoline, to the carbon fibre material, that, though being very expensive, is at the same time increasingly present in the automotive industry to reduce the weight of the newly designed models (Sciarra 2010 b).

As for the relocation of production, PSA Peugeot Citroen Group, like other major international producers, having previously concluded partnership in the Eastern countries (Hungary, Poland and Czech Republic), now appear to have oriented their investments to emerging markets like China, that after an agreement with Dongfeng, made another one for the joint-venture with Chang'an local firm.

The initial investment was fixed at 395 million Euros per year, for the construction of about 200,000 items, namely engines, commercial vehicles and French cars made in four factories. In addition, as compared to the agreement with Dongfeng selling models under the two brands of the French PSA Peugeot Citroen Group, the products manufactured by this joint venture will be marketed under a new brand (Sciarra $2010 \mathrm{c}$ ).

The strategies adopted by the Group seem to have brought about more significant results than expected for 2010, that, in the analysts' opinion would end with a profit slightly below one billion Euros. The end result was a net profit of 1.13 billion Euros that, compared to a loss of 1.16 billion Euros in 2009, represents an increase of $15.8 \%$ (ANSA 2011).

This result will allow the full redemption of the remainder of the 2 billion loan granted by the State, as well as stable results expected for 2011, which will facilitate the entry into some emerging markets such as Russia, whose growth is estimated at $15 \%$, China (where the three-volume 408 model will be presented, the model being designed specifically for the Chinese market), as well as Latin America with $10 \%$ and $4 \%$ growth respectively.

In addition, the special attention given to the environment, resulting from the recent agreement with Mitsubishi for the construction of the iOn electric car (a compact and handy utility passenger car with a top speed of $130 \mathrm{~km} / \mathrm{h}$ ), ranked the Group $1^{\text {st }}$ with regard to electric car market and allowed the Group itself to receive the "Energy and Mobility" prize for the production of the latest e-HDi diesel engine equipped with mass-produced StopStart, which will allow 15\% reduction in fuel within the whole range by 2011 .

\section{FIAT GROUP'S DEVELOPMENT STRATEGIES}

After examining the internationalization strategies of PSA Peugeot Citroen Group, it is useful to investigate into those implemented by Fiat Auto Group, even in view of a possible merger in the near future, as previously highlighted. 
The analysis carried out shows that, unlike PSA Peugeot Citroen Group, the development strategies of the Turin firm involve two main trends that can be described as follows. The first one is internationally-oriented through the relocation of the production process to countries offering such competitive advantages as low labour costs, cheap energy, tax incentives and so on, as evidenced by the latest joint venture between Fiat and the Serbian Government, which, in December 2009, gave birth to Fiat Automobiles Srbija (FAS), of which two-thirds are owned by Fiat and the remaining part by the Serbian Government that took over the Kragujevac-based Zastava Automobiles. The second trend is oriented to redesigning the governance within the company, by splitting the Group into two separate companies, namely Fiat Auto and Fiat Industrial (Scalera, 2011).

As to the first point, the agreement made with the Serbian Government provides that Fiat is going to make the most important foreign investment in the Balkan country (reaching 700 million Euros over three years) aimed at producing about 200,000 "LO" space wagon models in the former Zastava factory, thus replacing well-known models such as the Fiat Multipla, the Fiat Idea and the Lancia Musa.

The advantages of this agreement are related to the opportunity of producing cars at a competitive cost, due to the low cost skilled labour force whose wages are about 400 Euros per year, turning out to be well below both the Italian and Polish ones, reaching about 1,200 Euros and 600 Euros respectively (Di Napoli 2010).

Besides, the State bears the total cost of the factory decontamination (to dispose of about 370 tons of dioxins resulting from the Nato air raids in 1999, during the war that split the former Yugoslavia), handing over its ownership to the Fiat Group.

Another advantage which is not negligible concerns the number of employees that, at present, are paid by the Fiat Group. In fact, for the moment, only 1,060 out of the 2,600 total staff are paid by the Turin Company, while the remaining ones will be on the payroll of the Serbian Government until the development of the Kragujevac factory allows new recruitment for which, on the other hand, the "Lingotto factory" will be granted a loan of 10,000 Euros for each new employee by the Serbian Government.

In addition, the Italian motor company will be allowed remarkable tax reduction; in fact, it is not going to pay taxes either to Belgrade Government or to Kragujevac municipality for ten years.

The strategic importance of such an investment in the heart of the Balkan area is even linked to the fact that Fiat can use Serbia as a launching pad to market the product in Russia on highly competitive conditions, thanks to a free trade agreement involving also the motor industry. In fact, through the elimination of customs duties and with a view to achieving the ambitious goal of 200,000 cars exported per year, the above agreement will allow the Turin firm to earn 2,000 Euros more, on average, on each motor vehicle, for a total amount of 400 million Euros.

Moreover, the workers quitting the Zastava company of their own will benefit from a gratuity of 300 Euros for each year's service completed, while those employees that are not going to take legal proceedings against the firm to assert their own rights and to be paid off interest on the arrears from 1997 to 2001 will get a total settlement of the debt (for a total value of 10 million Euros) (Mijalkoviæ 2008).

Furthermore, thanks to a number of benefits and tax relief granted by the Serbian Government, the agreement is favourable to the Turin firm even on the fiscal side: the voluntary conveyance of the factories to the Fiat Group, exemption from paying taxes to the municipality for ten years, the creation of a "free zone" of 75 hectares (55 for the Fiat Group) (De Pascale 2009), in order to allow the duty-free import of goods from Italy, as well as the concession of another industrial estate to house 14 firms connected to Fiat (from Iveco to Ditec and Magneti Marelli) involved in the construction of a motorway link for the E75 aimed at improving the road network of the area.

Concerning the main disadvantages of the agreement, they are mostly of a social nature.

The above agreement has, in fact, brought about tension both in Serbia and in Italy. Indeed, in the Balkan country, following the production of the new Fiat Punto at the end of 2009, a fire was deliberately set to the factory in Kragujevac, destroying the conveyer belt between the painting line and the assembly line; the management considered this event as a warning sign aimed at urging more care in employing the staff.

In Italy, instead, there was much tension between the Turin firm and the unions concerning the Mirafiori factory that, as a matter of fact, lost the "LO" production. 
However, in the above factory, a referendum was held by the owners at the beginning of the year, concerning the acceptance or not of the new labour agreement, in exchange for considerable production investment reaching 1 billion Euros to produce new "luxury" models (like Jeep and Giulietta). The referendum was successful, with the favourable opinion of $54.1 \%$ of the workers, out of the total staff of 5,400 employees in the factory.

In particular, the agreement is penalizing for workers who, nevertheless, due to the current international economic recession, opted for keeping their job in spite of reduced rights.

Going further into details, the agreement provides for reduced breaks, shrinking from 40 to 30 minutes, with 32.47 Euros added, monthly, on the wage packet for the extra minutes worked, the nonpayment of the first day off sick for those employees who will be out shortly before holidays or on their weekly day off for more than twice a year, a 40-hour weekly work salary, including breaks, spread over a total of 18 work-shifts, compulsory overtime up to 80 hours per year and, above all, new sanctions about striking that can lead to the worker's dismissal if production is seriously damaged (Sciarra 2010d).

It is important to point out that the assent of almost all the trade unions to this independent contract providing that the Joint Trade Union Committee (JTUC) is replaced by the corporate one is only possible because the Fiat Group is no more party to the Italian Manufacturers' Association (Confindustria).

Another disadvantage is, however, linked to this corporate Taylor-style policy inhibiting workers from any kind of protest. Which, in the long run, is likely to bring about growing social unrest due to exhausting work-shifts, lack of dialogue with the top management, as well as a worker's wages which are not up to the average standard of living of the country. All these factors are likely to lead the employee to develop a state of depression thus causing either long periods of absenteeism from work or lesser commitment by the worker as compared with his own potential.

From the point of view of taxation, even if the elimination of customs duties allows the Russian market to collect 400 million Euros, considering 200,000 motor vehicles exported, this amount is not going to be cashed by the Turin firm but it will be handled by the Kragujevac joint company (Mijalkoviæ 2008).

Besides, it is to be pointed out that the incidence of the labour cost doesn't exceed $7 \%$ of the total capital in a highly complex and technologically advanced structure, with a final saving that, after all, should only reach $3 \%$ of the end-product. Which would make one consider that the GOM (Gross Operating Margin) is very scant if, to keep it steady, in this period of international recession, it is necessary to sacrifice the social peacefulness of the firm.

As to the internal strategy, aimed at changing the corporate organization, in order to expedite the decision-making process, as well as to achieve the flexibility needed to meet promptly the market's development, in September 2010, as already described above, the Fiat group split into two separate companies: Fiat Auto and Fiat Industrial. The first will include, besides Fiat Group Automobiles, such companies as Ferrari, Maserati, Magneti Marelli, Teksid, Comau and Fiat PowerTrain automobiles; the second will incorporate $\mathrm{CNH}$ and Iveco, in addition to the industrial and marine sector of Fiat PowerTrain.

This reorganisation will eventually allow the motor sector to go its own way and the management and funders to really understand the extent of the value yielded through the production and sale of cars. In fact, from a financial point of view, the above shake-up will also include a fair distribution of the industrial debt between the two groups reaching approximately 2.5 billion Euros as well as initial liquidity of 10 billion Euros for Fiat Automobiles and of 3 billion Euros for Fiat Industrial (Fornovo 2010).

In addition, the spin-off of the automotive industry from the industrial one has allowed Fiat Automobiles and Fiat Industrial shares to be quoted separately as from the beginning of the year; which was highly appreciated by the financial community.

In an international market which is currently experiencing a state of turmoil due to a proceess of continuous change influencing its evolution, the logic of this splitting is primarily oriented to preventing the heterogeneity of the businesses that made it up because of a clear difference distinguishing the two main activities as regards their specific features, commitments, capital profitability, margins and dynamics of their markets. 
This will enable each of the two business units to focus on its own SBA (Strategic Business Area) with goals easily identified and recognized by the market and to show specific features with strategies that are determined independently, as well as to bring out the amount of value that each entity is likely to yield.

Specifically, the Fiat Group will be able to better its competitive position on a world scale and to enhance its efficiency thanks to an alliance with Chrysler, whose share should reach $51 \%$ by the end of the year, benefiting from the best distribution in the Chrysler's sale network; which will allow Fiat to spread its brand internationally, giving birth to a "four-headed heart": Turin for the European market (that is going to control the Italian factories as well as those based in Poland, Serbia, Turkey and Russia), Detroit for the North-American one (covering American investments in addition to those in Canada and Mexico), Betim for South-America (that is going to control Brazil as well as Argentina) and finally Peking, for the Asian area (that is going to run the newly established Chinese factory in Changsha as well as India).

The results seem to support the Group's strategies, despite the cut in governmental incentives; in fact, it seems that, on one side, the Group's net proceeds have risen from 50,102 million Euros in 2009 to 56,258 million Euros in 2010 and, on the other one, the negative net result recorded in 2009, with a loss of 848 million Euros, was turned into a profit in 2010, with 600 million Euros. Finally, the car sector alone has increased the result concerning the ordinary management, shifting from 719 million Euros in 2009 to 934 in 2010, while, thanks mainly to the partnership with PSA Peugeot Citroen, vehicles have more than doubled their positive result, shifting from 105 million Euros in 2009 to 270 in 2010 (Molinengo 2011).

Prospects for the future are highly ambitious for the Turin firm whose turnover is expected to reach 64 billion Euros, within four years, which would actually double the amount expected for 2010, of which as much as $80 \%$ would result from Fiat Group Automobiles, $6 \%$ from Ferrari and Maserati, while the remaining part would come from component production (Fornovo 2010).

\section{THE ORGANIZATION OF PSA PEUGEOT CITROEN AND FIAT AUTO}

The analysis carried out on the companies' organizational structures of PSA Peugeot Citroen and Fiat Auto shows that the two manufacturers rely on the Toyotist principles based on the lean production model.

The reasons for this organizational orientation are related to the fact that the turbulence of the markets has changed the companies' strategic structure (meant as the company's organisation that is strategically relevant) that, being originally of a unitary kind (namely having a single competitive reference system), has got diversified (i.e. involving companies that are willing to compete in different areas and ranges of activities characterized by different reference economic operators and different rules).

As a result, it was necessary to support the corporate decision-system with a suitable organisational structure that was to be different from the hierarchic-functional one aiming at developing an analysis of the value chain carried out by function. In fact, it provided for segmentation into sub-systems of operations sharing the same "object" and hence the same professional skills, competence and resources called for, thus neglecting the distinction between the different kinds of activities and their own interconnections (Nelson 1988, Taylor 1969).

Instead, the purpose is that of segmenting the corporate system into processes both at a global level and for each single SBA (Strategic Business Area), which means subdividing the system into a set of sub-systems involving homogeneous activities that are interconnected and aimed at the creation of value for the customer, by transforming an input into an output (Bernardi and Biazzo 1996).

Thus, organisational redesigning has involved all the organisational variables (structure, technology, human resources) with the sole purpose to achieve maximum competitiveness on the market, thus meeting the customers' demand and improving the business performance through increased flexibility, innovativeness and corporate integration.

In particular, it is to be pointed out that this organisational structure is based on a set of fundamental criteria with which compliance is critical to the effectiveness and efficiency of the structure itself. They include: the process diversification, the decision-making power delegated to employees, the tasks unification, avoiding production waste thanks to the Just-in-time system, the process activity 
outsourcing, the total involvement of suppliers (Argyris 1995; Bartezzaghi et al. 1994; Benozzo and Piccardo 1995; Butera 1994; Camussone 1985; Cusumano 1985; Dubini and MacMillan 1991; Golhar and Stamm 1991).

Therefore, in the light of what examined above, it can be stated that the new organizational structure of the two producers considered radically changes the main criteria on which the old hierarchicalfunctional model was based, thus leading to replacing the management by "functions" with that by "process", to a complete redesigning of the decision-making system through the setting up of the "Business Units", as well as to abolishing the "teams" by establishing the "basic organizational Units" (Volpato 1996).

Ultimately, the benefits of this organisational reshaping are mainly two:

the first is the fact that, in this way, it is possible to understand the economic impact (cost) of each activity on the end- product;

the second one concerns the possibility of establishing what are the key business processes, namely those able to create value for the customer as well as of favouring those processes at the expense of others that do not allow such a result and are, therefore, eliminated from the company.

\section{CONCLUSIONS}

The present work was intended, first, to analyze the development strategies of PSA Peugeot Citroen Group, to assess whether such strategies were in line with market expectations, and secondly to compare them with those of the Fiat Auto Group, trying to understand the main differences between the two car makers, as well as to assess, subsequently, what organizational structure would best support the business goals planned.

Thus, the analysis carried out and the results examined show that, in the current international context, the automotive industry is definitely one of the most affected by the recent war in the Middle East, due to the evident rise in fuel prices.

In particular, the sector is characterized by a significant reduction in competition fragmentation, as compared to the past, owing to the creation of joint ventures between international manufacturers and local governments, especially in developing countries, as well as to the merger between traditionally leading producers, aiming at allowing the realization of those synergies ensuring its competitiveness.

Among those synergies, the one that is increasingly pushing its way among the others is that aiming at developing the expensive innovation concerning energy saving, in order to introduce either hybrid or electric engine cars, that in the current phase of serious international crisis, is increasingly a critical success factor to be met.

In particular, the PSA Peugeot Citroen Group's strategy is going this way, thus increasingly oriented towards environmental protection and energy saving, being well supported by the Government and the unions, so that they now rank $1^{\text {st }}$ for the production of electric vehicles in the international scene and represent, at present, $10 \%$ of the overall French car market, even thanks to 5,000 Euros discount on cars, funded by the State that is also committed to purchase these cars to renew the public car park.

The reasons for this result are related to two main factors. On one side, the availability of electricity in large quantities that are not exploited, due to the nuclear power plants production and that would encourage the development of infrastructures for recharging electric vehicles on the area; on the other one, the concern for the employment shortage in the French automotive industry, due to the relocation of production by the leading transalpine manufacturers that are concentrated on seeking low-cost labour in the emerging countries.

In fact, although they do not want to give up the idea of relocating activities abroad for the above reasons, on one side, in order to ensure the creation of value in A and B segments, which represent about $80 \%$ of the market, on the other one, it is also true that they are fully willing to produce electric cars locally; which would promote both employment and the increase in domestic sales, with the prospect of penetrating the Chinese market that appears to be the most attractive at an international level, due to high demand for cars as well as to tax relief granted for the production of electric cars.

Unfortunately, as to the electric car segment, the Fiat Group starts from a position of distinct disadvantage, since it cannot rely either on nuclear power or, for the moment on the Government's funding; such factors do not make the purchase cost of those vehicles very competitive, namely 35,000 Euros 
on average; in addition, they do not provide the national territory with a widespread supply network (Mombelli 2011).

Concerning the production location, the Fiat Group shows a greater geographical decentralization compared to PSA Peugeot Citroen Group, due to a more complete network of production and sales, supplied in all continents by a widespread organization known as "four-headed heart", in which the "heads" are represented by the parent company located in Turin for Europe, by Detroit headquarters of Chrysler in North America, by Betim for South America and Peking for Asia.

The reasons for this stronger decentralization, as compared to PSA Peugeot Citroen Group, are due, not only to the search for low cost labour, but also to the search for affordable energy resources and, above all, to the low level of productivity of the Italian factories, reaching $54 \%$ (this percentage falls to $37 \%$ if one considers the technical capacity), compared to the foreign ones in which the work commitment is equal to $126 \%$ (and to $78 \%$ considering the technical training of workers).

Unfortunately, this relocation has brought about considerable social tension in Italy which, especially following the decision to produce the "LO" model, originally planned in the Mirafiori plant in Turin, in the new one based in Kragujevac in Serbia.

It is to be noted that another aspect emerging from the analysis conducted on the two automotive groups examined is linked to their political re-launching.

In fact, the transalpine Group has focused its attention on its image restyling, by redesigning the brand, offering innovative advertising campaigns, a wide and various range of products focused on environmentally friendly and energy saving engines, as well as on an efficient after-sales service with the use of "Mu by Peugeot". On the contrary, the re-launching of the Fiat Group was different, aiming mainly at redefining the corporate structures both nationally, with the splitting giving birth to the two companies, namely Fiat and Fiat Auto Industrial, and internationally, with the acquisition of Chrysler.

The spin-off implemented has eliminated the heterogeneity of the business, thus allowing each SBA (Strategic Business Area), to determine specific objectives easily identified by the market, to expedite the decision-making process with independent strategies and to bring out the amount of value that each entity is likely to produce; instead, the French Group is still experiencing this kind of heterogeneity, due to not only to the merger of the automotive and business sectors into a single corporate structure but also for the presence of the Citroen brand.

As to the acquisition of Chrysler, it allows a more widespread distribution network at an international level, especially in North America, as well as the exploitation of the know-how in the standard and luxury segments of the American company to complete the product range, creating successful cars relying on quality engines and high technology in those segments where the Turin company is not competitive, being focused, mostly, on utility passenger cars.

Finally, as regards the organizational structure adopted by the two manufacturers, it was noted that the model used is the same, namely no longer the one based on functions, but one that focuses on processes, allowing the organisational efficiency and effectiveness to be improved, thus meeting a number of critical success factors represented by the following: the streamlining of production that is likely to better the business flexibility and the quality of the product, greater decision-making power delegated to employees, whose increased involvement leads to improving their commitment, minimized costs thanks to reducing the stock-in-trade as well as waste, improved information, whose effectiveness is ensured by the technological value of the computer system, reduced assembly time of the car through the location of suppliers close to the parent house and so on.

In conclusion, in the light of the analysis carried out, it can be stated that both the strategies adopted by the two manufacturers examined have been satisfactory and that, indeed, their merger, in the future, could be facilitated by a common organisational structure and it is likely to allow the transalpine Group to exploit the wider relocation of production and distribution of Fiat Auto to enter new markets, as well as its specialization in the production of utility passenger vehicles to get stronger in this segment; on the other side, the Italian company will be allowed to exploit the low cost of French energy in order to minimize production costs, as well as technology and the degree of specialization achieved in the segment of electric cars, to ensure the development of this segment in the domestic market, producing cars with an average cost lower than the present one. 


\section{REFERENCES}

1. ANSA (2011), PSA Peugeot-Citroen: It will Come in Handy 2010, 1.13 bn. Profits, http:// www.ansa.it/motori/notizie/rubriche/industriamercato/2011/02/09/ visualizza_new.html_1590487128.html, Accessed January 13, 2011.

2. Argyris, C. (1995), Dialogue as a Way to Achieve Better Results in the Company, Harvard Business Review, No. 2.

3. Bartezzaghi, E., Spina, G. and Verganti, R. (1994), More Flexible Technologies for the New Entrepreneurial Models, L'impresa, No. 3.

4. Benozzo, A. and Piccardo, C. (1995), Empowered Teams, Sviluppo \& Organizzazione, No. 150.

5. Bernardi, G. and Biazzo, S. (1996), Analysis and Representation of the Corporate Processes, Sviluppo \& Organizzazione, No. 156.

6. Bourassi, N. (2010), PSA have Reached a Turning Point in their Strategy of Luxury Car Production, easybourse, http://www.easybourse.com/bourse/automobile/article/17807/psa-a-un-tournant-dans -sa-strategie-de-montee-en-gamme.html, Accessed January 14, 2011.

7. Brusa, L. (1986), Corporate Organisational Structures, Giuffré Editore, Milano.

8. Butera, F. (1994), From Hierarchy to Teams: this Is how Power is Changing within the Company, L'impresa, No. 4.

9. Camussone, P. F. (1985), The Informational System in the Company, Etas Libri, Milano.

10. Cusumano, M. (1985), The Japanese Automobile Industry, Harvard University Press, Cambridge.

11. De Pascale, A. (2010), Fiat's Removal to Serbia, Terra news, http://www.terranews.it/ news/2010/07/il-trasloco-di-fiat-serbia, Accessed January 15, 2011.

12. Donna, G. (1992), The Competitive Business, Giuffré Editore, Milano.

13. Dubini. P. and MacMillan, I. C. (1991), Strategies for Technological Change, Sviluppo \& Organizzazione, No. 128.

14. Fornovo, L. (2010) The Company has Given the Go-ahead. Here Is the New Fiat, La Stampa.it, http://www.lastampa.it/redazione/cmsSezioni/economia/201009articoli/58615girata.asp, Accessed March 2, 2011.

15.Gemelli, F. (2010), The Peugeot of the New Decade, Omniauto.it, http://www.omniauto.it/ magazine/10767/la-peugeot-del-nuovo-decennio, Accessed January 18, 2011.

16. Giorgi, F. (2009), Changes in the PSA Peugeot Citroen Group's Top Management, Motori.it, http://www.motori.it/attualita/1493/cambi-al-vertice-nel-gruppo-psa-peugeot-citroen.html, Accessed March 3, 2011.

17. Golhar, D. and Stamm, C. L. (1991), The Just-in-Time Philosophy: a Literature Review, International Journal of production Research, Vol. 29, No.4.

18. Loubet, J. L. (1995), Citroen, Peugeot, Renault and the Others:a Sixty-Year Strategy, Collection Mémoire Le Monde Editions, Paris.

19. Miolo Vitali, P. (1993), The Corporate Decision-Making System, Giappichelli Editore, Torino.

20. Molinengo P. (2011), Fiat: the Group's Consolidated Balance Sheet was Adopted, http://

it.finance.yahoo.com/notizie/Fiat-approvato-bilancio-trend-2784448411.html? $\mathrm{x}=0$, Accessed March 5, 2011.

21. Mombelli M. T. (2011), In Italy the Electric Car is not Going to Make its Way, Business People, http://businesspeople.it/Ambiente/Green-living/In-Italia-l-auto-elettrica-non-fa-strada_17516, Accessed January 19, 2011.

22. Montrone, D. (2010), Fiat: does Marchionne Think about Involving Cars as well in the Alliance with PSA Peugeot Citroen?, http://www.autoblog.it/post/26355/fiat-marchionne-pensa-allalleanza-con -psa-peugeot-citroen-anche-per-le-auto, Accessed January 21, 2011.

23. Nelson, D. (1988), Taylor and the Managerial Revolution, the Origin of the Scientific Management, Einaudi, Torino. 
24. Porter, M. (1993), The Competitive Advantage, Edizioni Di Comunità, IV Edizione, Milano.

25. Prahalad, C. K. and Hamel, G. (1990), The Core Competence of the Corporation, Harvard Business Review, No. 3.

26. Scalera, F. (2011), "Internationalization Strategies of Fiat Auto to Tackle the Crisis: the Case of Fiat Automobiles Srbija", Proocedings Book $3^{\text {rd }}$ International Scientific Conference "Economic Policy and EU Integration", Faculty of Business, "Alexsandër Moisiu University, Durrës, Albania, April 8-9, 2011, Vol.2, pp. 67-87.

27. Sciarra, F. (2010a), Peugeot-Citroen: 200 Million European Loan for Hybrid Cars, plug-in, Autoblog.it, http://www.autoblog.it/post/28212/peugeot-citroen-prestito-europeo-da-200-milioni-perle-ibride-plug-in, Accessed March 7, 2011.

28. Sciarra, F. (2010b), BMW-Peugeot-Citroen: Will the Agreement Involve Carbon Fibres as well?, Autoblog.it, http://www.autoblog.it/post/29420/bmw-peugeot-citroen-laccordo-si-estendera-alla-fibradi-carbonio, Accessed March 17, 2011.

29. Sciarra, F. (2010c), Peugeot-Citroen: New Joint-Venture in China. A Third Brand is Going to Be Born, Autoblog.it, http://www.autoblog.it/post/28131/peugeot-citroen-nuova-joint-venture-in-cinanascera-un-terzo-marchio, Accessed March 18, 2011.

30. Sciarra, F., (2010d), Fiat has Reached an Agreement for Mirafiori, a Billion-Worth of Investments. Fiom Says No. All the Points of the Understanding, Autoblog.it, http://www.autoblog.it/ post/31017/fiat-accordo-raggiunto-per-mirafiori-investimenti-per-un-miliardo-no-della-fiom-tutti-ipunti-dellintesa, Accessed March 19, 2011.

31. Tanca, M. (2010), Peugeot is Now 200 Years Old!, Moto.It, http://www.moto.it/news/peugeotcompie-200-anni.html, Accessed January 22, 2011.

32. Taylor, W. (1969), The Scientific Organization of Work, Etas, Milano.

33. Volpato, G. (1996), The Fiat Case. A Strategy of Reorganisation and Relaunching, Isedi, Torino. 